The Chinese and the Iron Road 
This page intentionally left blank 
A S I A N A M E R I C A

A series edited by Gordon H. Chang 


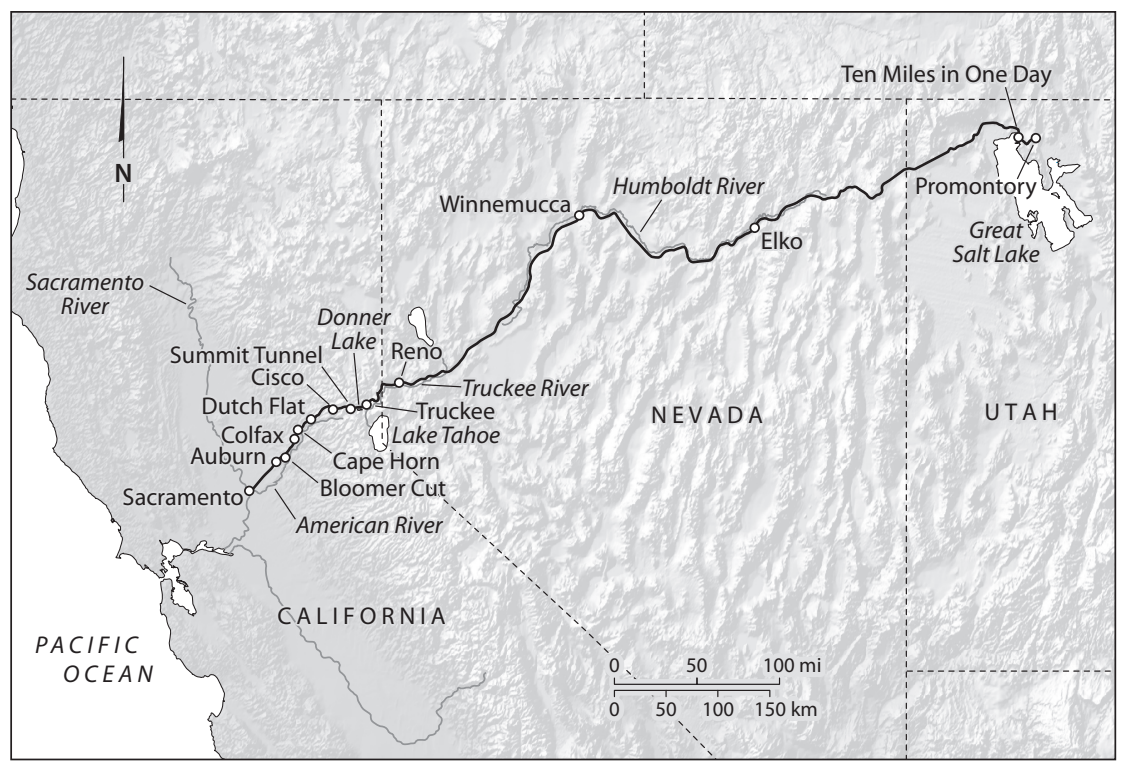

Central Pacific Railroad Line 


\section{The Chinese and the Iron Road}

B U I L D I N G T H E

T R A N S C O N T I N E N T A L

R A I L R O A D

E D I T E D B Y

Gordon H. Chang and Shelley Fisher Fishkin, with Hilton Obenzinger and Roland Hsu 
Stanford University Press

Stanford, California

(C) 2019 by the Board of Trustees of the Leland Stanford Junior University. All rights reserved.

No part of this book may be reproduced or transmitted in any form or by any means, electronic or mechanical, including photocopying and recording, or in any information storage or retrieval system without the prior written permission of Stanford University Press.

Printed in the United States of America on acid-free, archival-quality paper

Library of Congress Cataloging-in-Publication Data

Names: Chang, Gordon H., editor. | Fishkin, Shelley Fisher, editor. | Obenzinger, Hilton, contributor. | Hsu, Roland, 1961- contributor.

Title: The Chinese and the iron road : building the transcontinental railroad / edited by Gordon H. Chang and Shelley Fisher Fishkin, with Hilton Obenzinger and Roland Hsu.

Other titles: Asian America.

Description: Stanford, California : Stanford University Press, 2019. | Series: Asian America | Includes bibliographical references and index.

Identifiers: LCCN 2018037786 | ISBN 9781503608290 (cloth : alk. paper) | ISBN 9781503609242 (pbk.) | ISBN 9781503609259 (epub)

Subjects: LCSH: Railroad construction workers-West (U.S.) - History-19th century. | Foreign workers, Chinese-West (U.S.) - History—19th century. | Central Pacific Railroad CompanyEmployees-History. | China-Emigration and immigration-HistoryI9th century. | Chinese-West (U.S.) - History—19th century. | West (U.S.) - History- I9th century.

Classification: LCC HD8039.R3152 C49 2019|DDC 331.6/251097509034-dc23 LC record available at https://lccn.loc.gov/ 2018037786

Cover design: Susan Zucker

Cover photo: China Section Gang Promontory, J. B. Silvis. Denver Public Library.

Typeset by BookMatters in II/I4 Garamond Premier Pro 